\title{
Changes in Guanosine 5'-Diphosphate 3'-Diphosphate (ppGpp) Content of Rhodopseudomonas sphaeroides f. sp. denitrificans during Adaptation for Growth under Denitrifying Conditions
}

\author{
By WOJCIECH P. MICHALSKI AND D. J. D. NICHOLAS* \\ Department of Agricultural Biochemistry, Waite Agricultural Research Institute, \\ University of Adelaide, Glen Osmond 5064, South Australia, Australia
}

(Received 13 December 1984 ; revised 8 May 1985)

\begin{abstract}
Changes in the concentrations of guanosine $3^{\prime}$-diphosphate $5^{\prime}$-diphosphate (ppGpp) in Rhodopseudomonas sphaeroides $\mathrm{f}$. sp. denitrificans were followed during adaptation for growth under denitrifying conditions. The addition of nitrate or nitrite to photosynthetically-grown ${ }^{32} \mathrm{P}-$ labelled cells resulted in a rapid intracellular accumulation of $\left[{ }^{32} \mathrm{P}\right] \mathrm{ppGpp}$. Coincident with the rise in concentration of the nucleotide there was an abrupt decrease in the rate of $\left[{ }^{3} \mathrm{H}\right]$ uridine incorporation into acid-precipitable cell material. Under these conditions an enhancement of nitrate and nitrite reductase activities was observed. However, washed cells preincubated with $5 \mathrm{~mm}$-ascorbate for $60 \mathrm{~min}$ did not accumulate $\mathrm{ppGpp}$ in response to the addition of nitrate, but the denitrifying enzymes were synthesized. The data indicate an involvement of ppGpp in regulating denitrification, possibly in response to changes in the distribution of available reducing equivalents between photosynthesis and denitrification linked electron transfer when nitrate is included in the growth medium.
\end{abstract}

\section{INTRODUCTION}

In the heterotrophic bacteria, nutritional and/or energy stress results in a so-called stringent response associated with abrupt changes in many biochemical reactions (for reviews see Cashel, 1975; Nierlich, 1978). Studies with Escherichia coli (Gallant, 1979) have shown that phospholipid and carbohydrate synthesis, the production of stable RNA, and membrane transport of nucleobases are all under the control of the rel $A$ locus. Thus, amino acid starvation of $\mathrm{rel} \mathrm{A}^{+}$(stringent) strains of $E$. coli results in an immediate restriction of stable RNA accumulation, together with a number of other physiological adjustments. The product of the $\mathrm{rel} A$ locus is a ribosome-associated protein (stringent factor) which mediates the production of guanosine 5'-triphosphate 3'-diphosphate (pppGpp) in response to elevated intracellular levels of uncharged tRNA. The pppGpp produced is then rapidly converted to guanosine $5^{\prime}-$ diphosphate $3^{\prime}$-diphosphate (ppGpp), which subsequently reaches a significant intracellular concentration $(>1 \mathrm{mM})$ in amino acid-starved $\mathrm{rel} \mathrm{A}^{+}$cells. Relaxed mutants $(\mathrm{rel} A)$, which continue to accumulate RNA during amino acid starvation, fail to accumulate ppGpp and pppGpp under these conditions (Gallant, 1979).

The guanosine nucleotides ppGpp and pppGpp have been identified in Rhodopseudomonas sphaeroides, Rhodospirillum rubrum and Rhodopseudomonas palustris, supporting a suggestion that these are ubiquitous compounds in bacteria (Eccleston \& Gray, 1973; Loewen, 1976; Zumft \& Neumann, 1983). A regulatory role for ppGpp, similar to that in other heterotrophic bacteria, has also been proposed. Campbell \& Leuking (1983) have reported that ppGpp is involved in the regulation of phospholipid synthesis in $R$. sphaeroides, in agreement with an earlier report for cells undergoing an energy downshift (exposure to decreased light intensity) (Eccleston \& Gray,

\footnotetext{
Abbretiations: BVH, benzyl viologen (reduced form); DCPIP, 2,6-dichlorophenolindophenol; PEI-cellulose, polyethyleneimine-impregnated cellulose.
} 
1973). Zumft \& Neumann (1983) have shown that in $R$. palustris, ppGpp levels respond to the general nitrogen nutritional status of the cell and they suggested a regulatory role for this nucleotide in nif (nitrogen fixation) gene expression.

In this paper, we propose a role for ppGpp in $R$. sphaeroides $\mathrm{f}$. sp. denitrificans during its adaptation to denitrifying conditions, when nitrate and nitrite reductases are produced (cf. Michalski \& Nicholas, 1984a).

\section{METHODS}

Organism and growth conditions. Rhodopseudomonas sphaeroides f. sp. denitrificans strain IL 106 was kindly supplied by Dr T. Satoh (Department of Biology, Faculty of Science, Tokyo Metropolitan University, Tokyo 158, Japan). Cells were grown $(5 \%, \mathrm{v} / \mathrm{v}$, inoculum) in a liquid culture (Satoh et al., 1976) with modifications as described previously (Kelley et al., 1982). DL-Malate $(21.4 \mathrm{mM})$ and $\mathrm{NH}_{4} \mathrm{Cl}(12 \mathrm{mM})$ were included as carbon and nitrogen sources. Cells were grown photoheterotrophically at $30^{\circ} \mathrm{C}$ under anaerobic conditions in completely filled screwcap bottles $(250 \mathrm{ml})$ illuminated with $5000 \mathrm{~lx}$ white light $\left(7.35 \mathrm{~W} \mathrm{~m}^{-2}\right)$. Cell growth was monitored by measuring $\mathrm{OD}_{6(1)}$. Dry weights were determined as described previously (Hillmer \& Gest, 1977). Cell-free extracts were prepared by disruption of washed cells with two passages through a French pressure cell at $25000 \mathrm{lbf} \mathrm{in}^{-2}$ (approximately $0.17 \mathrm{GPa}$ ) followed by centrifugation at $15000 \mathrm{~g}$ for $20 \mathrm{~min}$ at $4{ }^{\circ} \mathrm{C}$ (Michalski \& Nicholas, $1984 \mathrm{a}$ ).

Nucleotide labelling with $\left[{ }^{32} \mathrm{P}\right]$ phosphate. Photosynthetically-grown cells were harvested at mid-exponential stage $(12 \mathrm{~h})$ and resuspended in $20 \mathrm{ml}$ fresh growth medium containing $50 \mathrm{~mm}-\mathrm{Tris} / \mathrm{HCl}(\mathrm{pH} 7.5)$ instead of potassium phosphate. Cell-suspensions (approx. $1 \mathrm{mg}$ dry weight $\mathrm{ml}^{-1}$ ) were then incubated for $4 \mathrm{~h}$ in the light $(5000 \mathrm{~lx})$ under argon, with $50 \mu \mathrm{Ci}$ carrier-free potassium [ ${ }^{3}: \mathrm{P}$ ] orthophosphate (Amersham; $37 \mathrm{MBq} \mathrm{m}{ }^{-1}$ ) to ensure adequate labelling of the cellular nucleotide pool. Unlabelled cell suspensions were prepared in parallel experiments for the assay of enzyme activities as well as $\left[{ }^{3} \mathrm{H}\right]$ uridine uptake studies.

Extraction and separation of nucleotides. Samples of cell suspension (100 $\mu 1)$ were extracted for 15 min with $50 \mu 1$ ice-cold formic acid $(99 \%, \mathrm{v} / \mathrm{v})$ according to the method of Zumft \& Neumann (1983). Precipitated material was pelleted by centrifugation ( $2 \mathrm{~min}$ at $15000 \mathrm{~g}$ ). Samples of the supernatant $(10 \mu \mathrm{l})$ was spotted onto PEI-cellulose $\mathrm{F}$ plastic sheets (Merck), and developed in one dimension with $1.5 \mathrm{M}-\mathrm{KH}_{2} \mathrm{PO}_{4}, \mathrm{pH} 3.4$ (Cashel et al., 1969). For twodimensional chromatography, the PEI-cellulose $\mathrm{F}$ sheets $(10 \times 10 \mathrm{~cm})$ were developed in the first dimension with 1.5 $\mathrm{M}$-LiCl in $2 \mathrm{M}$-formic acid (Gallant et al., 1976), then dried with warm air and washed for $30 \mathrm{~min}$ in methanol (Randerath \& Randerath, 1964). After drying again, the sheets were developed as for one-dimensional chromatography. Nucleotides were located by their fluorescence in UV light $(\sim 360 \mathrm{~nm})$ or by autoradiography, and were identified by comparing their positions on chromatograms with those of individually chromatographed authentic markers (pppGpp and ppGpp were from Calbiochem-Behring Australia; GTP, ATP, ADP, AMP were from Sigma). Radioactive spots containing ppGpp were scraped off the foil into scintillation vials and extracted overnight with $0 \cdot 1 \mathrm{M}$-potassium phosphate; they were radioassayed with scintillation fluor (phase-combining system, Amersham) in a Packard Tri-Carb liquid scintillation spectrometer (model $460 \mathrm{CD}$ ).

$\left[{ }^{3} \mathrm{H}\right]$ Uridine uptake. Samples $\left(200 \mu \mathrm{l}\right.$ ) of unlabelled culture (approx. $1 \mathrm{mg}$ dry wt $\mathrm{mol}^{-1}$ ) were sedimented for $30 \mathrm{~s}$ in an Eppendorf centrifuge. Harvested cells, resuspended in $200 \mu \mathrm{l}$ of fresh growth medium containing $50 \mathrm{~mm}$ Tris $/ \mathrm{HCl}(\mathrm{pH} 7.5)$ instead of potassium phosphate, were added to $6 \mathrm{ml}$ test tubes containing $3 \mu \mathrm{Ci}\left[5,6{ }^{3} \mathrm{H}\right] \mathrm{uridine}$ (Amersham: $1.48 \mathrm{TBq} \mathrm{mmol}{ }^{-1}$ ). The reaction mixture was continuously sparged with argon. Incubation was continued at $30^{\circ} \mathrm{C}$ for $2 \mathrm{~min}$ before $4 \mathrm{ml}$ ice-cold $5 \%(\mathrm{w} / \mathrm{v})$ TCA was added. The TCA precipitates were collected and washed on Millipore HA filters, then dried, placed in scintillation vials containing scintillation fluor (Readysolv HP, Beckman) and counted in the Packard Tri-Carb liquid scintillation spectrometer.

Enzyme assays. Nitrate reductase (EC 1.7.99.4) and nitrite reductase (EC 1.7.2.1) activities were assayed spectrophotometrically (Michalski \& Nicholas, 1984a). Nitrogenase activity in washed cells was determined by the acetylene reduction technique as described by Michalski \& Nicholas (1984b). Nitrite was measured as described by Nicholas \& Nason (1954). Protein content in crude extracts was determined by the method of Bradford (1976), using bovine serum albumin as a standard.

\section{RESULTS}

\section{Identification of $p p G p p$}

Light-dependent changes in the amounts of an oligo-phosphorylated nucleoside which migrated like ppGpp on one-dimensional PEI cellulose TLC have been reported in $R$. sphaeroides (Eccleston \& Gray, 1973). However, the nucleotide was poorly separated from material remaining at the origin and reliance on only one-dimensional chromatography for the identification of ppGpp has been criticized (Cashel, 1975; Loewen, 1976; Zumft \& Neumann, 

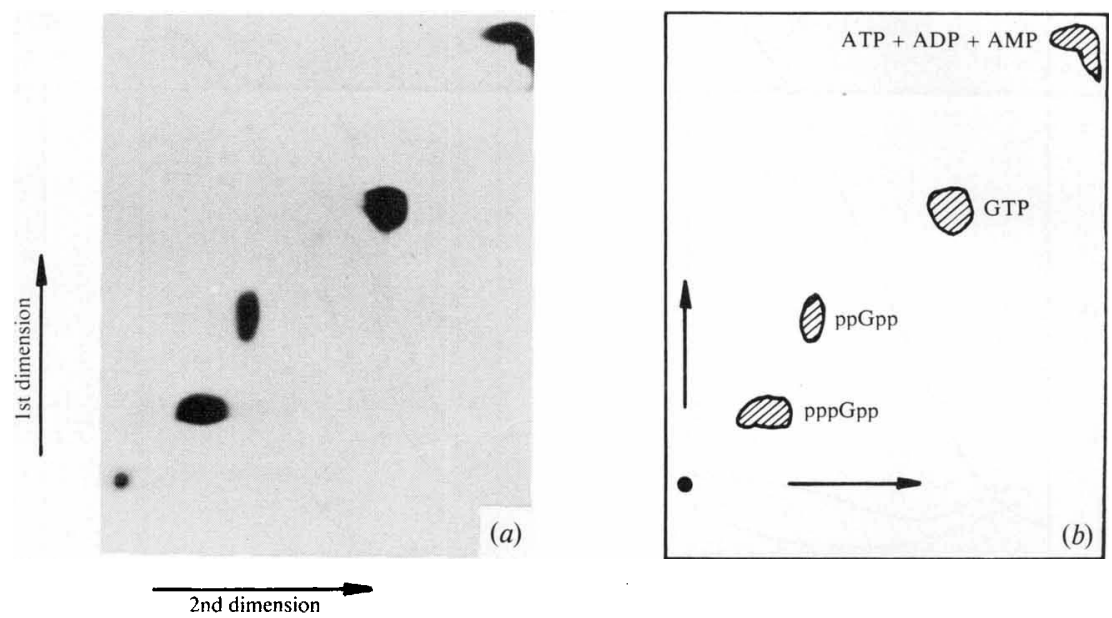

Fig. 1. Resolution and identification of guanosine nucleotides by two-dimensional TLC. Formic acid extracts of washed cells from ${ }^{32} \mathrm{P}$-labelled cultures grown with nitrate were spotted, together with authentic markers (pppGpp, ppGpp, GTP, ATP, ADP and AMP; $20 \mu \mathrm{g}$ each) onto PEI-cellulose sheets and co-chromatographed as described in Methods. The location of nucleotides was determined by their fluorescence in UV light $(\sim 360 \mathrm{~nm})(a)$; radioactive nucleotides were located by autoradiography $(b)$. The nucleotides were identified by comparing their positions on chromatograms with those of authentic markers.

1983). In our hands, the separation of phosphorylated nucleosides by one-dimensional chromatography was unsatisfactory, since we could not discount the possibility of another highly phosphorylated nucleoside co-migrating with ppGpp (cf. Loewen, 1976). Therefore, in this study the nucleotides ppGpp and pppGpp were identified unequivocally and quantified in formic acid extracts of ${ }^{32} \mathrm{P}$-labelled cells by using two-dimensional chromatography. Individual nucleotides were separated as sharp spots even on mini-PEI cellulose sheets $(10 \times 10 \mathrm{~cm})(\mathrm{Fig}$. 1). Radioactive ppGpp also migrated as a single spot on normalized sheets $(20 \times 20 \mathrm{~cm})$ and cochromatographed with authentic ppGpp.

\section{Activity of denitrifying enzymes in phototrophically-grown cells}

It was previously shown that although nitrate and nitrite reductases are constitutive enzymes in $R$. sphaeroides $\mathrm{f}$. sp. denitrificans, the addition of nitrate to photosynthetically-grown cultures enhanced the synthesis of both enzymes (Michalski \& Nicholas, 1984a). As shown in Fig. 2, the growth rate of cultures supplemented with $20 \mathrm{~mm}$-nitrate was virtually the same as that of cultures grown in light without nitrate. The maximum activity of nitrate reductase in such cultures was recorded within $8-10 \mathrm{~h}$ of growth with nitrate and was followed by a rapid accumulation of nitrite (up to $5 \mu \mathrm{mol} \mathrm{mi}^{-1}$ ) in the culture medium. Nitrite reductase, however, reached a maximum activity $6-8 \mathrm{~h}$ later (after $16-18 \mathrm{~h}$ of growth) (Fig. $2 b$ ). At the stationary stage of growth the culture medium still contained high concentrations of nitrite (5 mM) and residual nitrate (3-4 mM). In the cultures grown with $10 \mathrm{~mm}$ (or less) nitrate, an identical pattern of enzyme production was recorded but neither nitrate nor nitrite were detected in cultures at the stationary stage of growth (results not shown). These results indicate that the enhancement of the activities of nitrate and nitrite reductases resulted from increased substrate concentrations (nitrate and nitrite) for the two enzymes.

\section{Levels of ppGpp in cells grown in the presence of nitrate in the light}

The so-called stringent control in heterotrophic bacteria is characterized by two phenomena: (i) increased production of intracellular ppGpp and (ii) reduced synthesis of stable RNA, measured as a lowered rate of incorporation of $\left[{ }^{3} \mathrm{H}\right]$ uridine into acid-precipitable cell material (Gallant, 1979). 

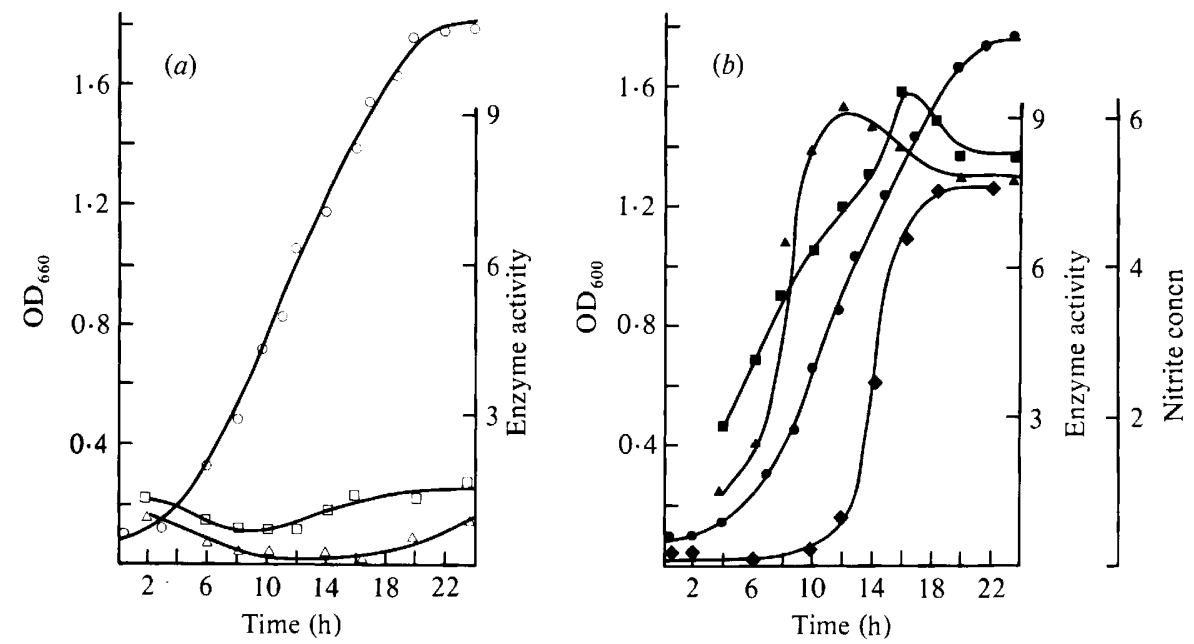

Fig. 2. Growth characteristics and activity of denitrifying enzymes of $R$. sphaeroides $\mathrm{f}$. sp. denitrificans grown photosynthetically $(a)$ without potassium nitrate or $(b)$ with 20 mM-potassium nitrate. $\bigcirc, O$, Bacterial growth. Nitrate reductase $(\triangle, \boldsymbol{\Delta})$ and nitrite reductase $(\square, \square)$ activities were measured in crude extracts [supernatant after centrifugation of disrupted cells at $15000 \mathrm{~g}$ for $20 \mathrm{~min}$ (see Methods)]. Their activity is expressed as $\mu \mathrm{mol} \mathrm{BVH}$ oxidized $\mathrm{min}^{-1}(\mathrm{mg} \text { protein })^{-1}$. The concentration of nitrite $(\bullet$, $\mu \mathrm{mol} \mathrm{ml} \mathrm{m}^{-1}$ ) in the culture medium was assayed as described in Methods.
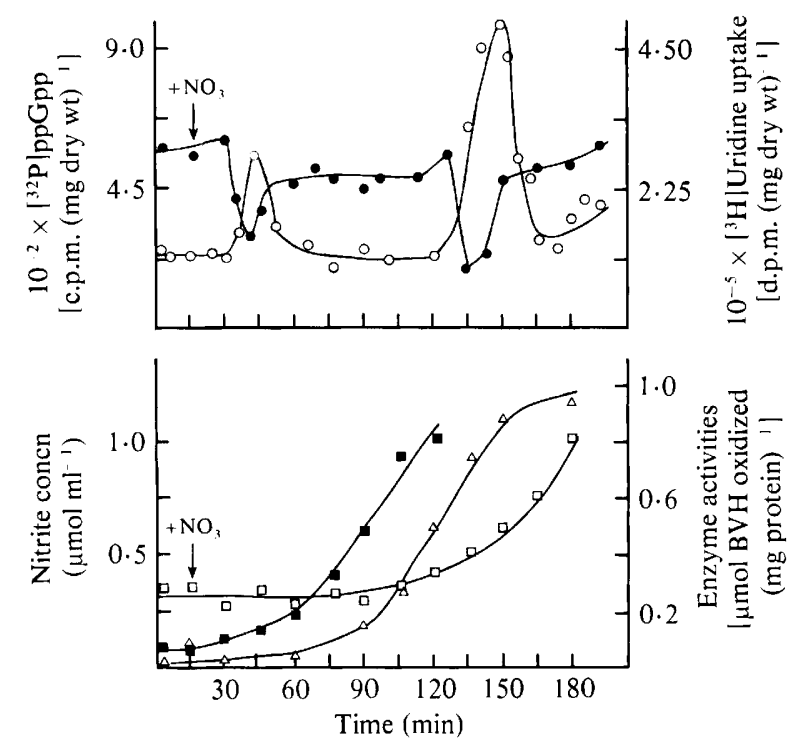

Fig. 3. Effect of nitrate on $(O)$ ppGpp content, $(O)$ the rate of $\left[{ }^{3} \mathrm{H}\right]$ uridine uptake and activities of denitrifying enzymes in $R$. sphaeroides f. sp. denitrificans. Nitrate ( $20 \mathrm{~mm}$ final concentration) was added to photosynthetically-grown cultures at the time indicated. Kinetics of ppGpp changes were studied in "2P-labelled cells as described in Methods. The activity of nitrate ( $\square$ ) and nitrite $(\square)$ reductases was measured in washed cell suspensions, whereas the accumulation of nitrite $(\triangle)$ was measured in culture media from which cells had been removed. Values from four separate experiments did not vary by more than $\pm 20^{\circ}$.

At the early exponential stage of growth the addition of $20 \mathrm{~mm}$-nitrate to ${ }^{32}$ P-labelled, photosynthetically growing cells resulted in a rapid intracellular accumulation of [ $\left.{ }^{32} \mathrm{P}\right] \mathrm{ppGpp}$ (Fig. 3). Under these conditions, there were two peaks of nucleotide accumulation occurring $30 \mathrm{~min}(150 \%$ above control $)$ and $130 \mathrm{~min}(350 \%$ above control $)$ after adding nitrate; coincident with the rises in the ppGpp levels there were abrupt decreases in the rate of $\left[{ }^{3} \mathbf{H}\right]$ uridine 


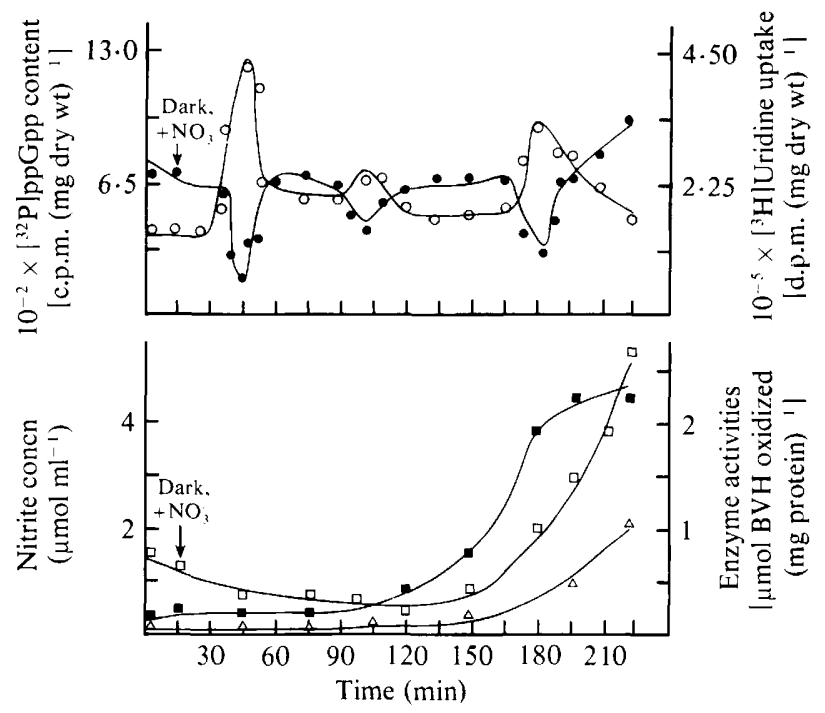

Fig. 4. Changes in (O) ppGpp content, (O) the rate of $\left[{ }^{3} \mathrm{H}\right]$ uridine uptake and activities of denitrifying enzymes in $R$. sphaeroides $\mathrm{f}$. $\mathrm{sp}$. denitrificans. Photosynthetically-grown cultures of $R$. sphaeroides $\mathrm{f}$. $\mathrm{sp}$. denitrificans were transferred to the dark and subsequently supplied with nitrate ( $20 \mathrm{~mm}$ final concentration) at the time indicated. The kinetics of changes in ppGpp content were studied in 32Plabelled cultures as described in Methods. The activity of nitrate $(\square)$ and nitrite $(\square)$ reductases was measured in washed-cell suspensions, whereas the accumulation of nitrite $(\triangle)$ was assayed in culture medium from which cells had been removed. Values from four independent experiments did not vary by more than $\pm 20^{\circ}$.

incorporation. A rapid increase of nitrate reductase activity commenced $45 \mathrm{~min}$ after the addition of nitrate. The accumulation of nitrite in the culture medium, due to nitrate reductase activity, occurred after $60-150 \mathrm{~min}$ growth and was followed by a pronounced increase of nitrite reductase activity.

Levels of ppGpp in cells grown in the presence of nitrate in the dark

$R$. sphaeroides $\mathrm{f}$. $\mathrm{sp}$. denitrificans can grow in the light under anaerobic conditions or in the dark in air. In the dark it can also grow while generating ATP by nitrate respiration (Satoh, 1981; Kelley et al., 1982; Michalski \& Nicholas, 1984a).

When photosynthetically-grown cells were supplied with $20 \mathrm{~mm}$-nitrate and transferred into the dark, the accumulation of ppGpp occurred after three time periods: 30,90 and 170 min (Fig. 4). Again, an abrupt decrease in the rate of $\left[{ }^{3} \mathrm{H}\right]$ uridine incorporation into acid-precipitable cell material coincided with a rise in ppGpp levels. A ten-fold increase of nitrate reductase was detected within $150 \mathrm{~min}$ of growth, and the accumulation of nitrite resulted in an enhancement of nitrite reductase activity.

\section{Induction of nitrite reductase activity by nitrite}

Although cells of $R$. sphaeroides $\mathrm{f}$. sp. denitrificans grew well under denitrifying conditions even in the presence of a large amount of nitrite (approximately $5 \mathrm{~mm}$ produced by reduction of nitrate), the addition of $\geqslant 2 \mathrm{~mm}$-nitrite to cultures at the beginning of the exponential phase completely restricted growth. However, within $30 \mathrm{~min}$ of adding $1 \mathrm{~mm}$-nitrite to ${ }^{32}$ P-labelled cells (see Methods) there was a rapid accumulation of ppGpp, followed by an increase in nitrite reductase activity, although growth resumed at a lower rate. The amount of nitrite in the culture medium decreased by approximately a half after a $3 \mathrm{~h}$ incubation, indicating that nitrite reductase was active in cito, i.e. it was able to reduce nitrite by using an endogenous electron donor (Fig. 5). 


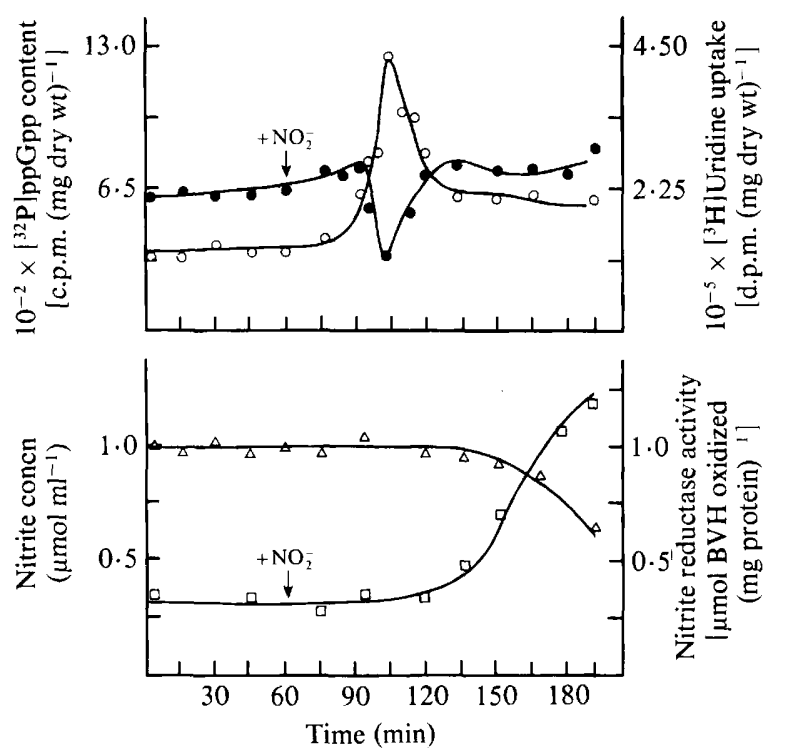

Fig. 5. Effects of nitrite (added at the time indicated) on (O) ppGpp content, (O) the rate of $\left[{ }^{3} \mathrm{H}\right]$ uridine uptake and $(\square)$ nitrite reductase activity. $\triangle$, Concentration of nitrite in the culture medium. Experimental conditions were as described in Methods. Values from three experiments did not vary by more than $\pm 15 \%$.

\section{Soluble cytochromes and the effect of ascorbate on denitrifying cultures}

The soluble fraction from cells grown without nitrate contained at least two low molecular weight $c$-type cytochromes, one of which was not detected in the corresponding fraction from denitrifying cells (W. P. Michalski, D. J. Miller and D. J. D. Nicholas, unpublished results). Some of the soluble $c$-type cytochromes in non-denitrifying cells had low redox potentials $\left(E_{m}\right.$ over the range -0.5 to $+0.1 \mathrm{~V}$ ) since sodium dithionite reduced-minus-ascorbate/DCPIP reduced difference spectra showed a peak at $550 \mathrm{~nm}$. However, cytochromes in the soluble fraction from denitrifying cells were fully reduced by ascorbate/DCPIP and thus had higher potentials than approximately $+0 \cdot 1 \mathrm{~V}$, the $E_{m}$ value for ascorbate being approximately $+0 \cdot 05 \mathrm{~V}$.

The addition of potassium ascorbate ( $3-5 \mathrm{~mm}$ ) to denitrifying cultures had no effect on the rate of cell growth or on the activities of $\mathrm{BVH}$-linked nitrate and -nitrite reductases in vitro. However, under these conditions the cells utilized nitrate and nitrite almost twice as fast as they did when ascorbate was omitted, indicating that ascorbate could act as an electron donor for nitrate and nitrite reduction in vivo. The cells did not accumulate either $\left[{ }^{32} \mathrm{P}\right] \mathrm{ppGpp}$ or [32P]pppGpp when nitrate (20 mM) or nitrite ( $1 \mathrm{mM})$, respectively, was added to ${ }^{32} \mathrm{P}$-labelled cultures that had been preincubated for $60 \mathrm{~min}$ with $5 \mathrm{~mm}$-potassium ascorbate.

\section{Levels of ppGpp during nitrogenase derepression}

Cultures of purple non-sulphur photosynthetic bacteria supplied with a limiting amount of $\mathrm{NH}_{4} \mathrm{Cl}$ utilize this nitrogen source during growth and then become starved of nitrogen. This effect is similar to a nutritional shift-down (amino acid starvation) in heterotrophic bacteria, which triggers the stringent response (Gallant, 1979).

Zumft \& Neumann (1983) have reported that the ppGpp level in $R$. palustris responded to the general nitrogen-nutritional status of the cell. On repeating this experiment with $R$. sphaeroides f. sp. denitrificans we obtained similar results (Fig. 6).

When ammonia-grown, ${ }^{32} \mathrm{P}$-labelled cells were sparged with argon without an alternative source of nitrogen, an immediate but transient increase $(200 \%)$ in the intracellular ppGpp occurred. The maximal level of ppGpp, about twice the initial value, was reached about $45 \mathrm{~min}$ 


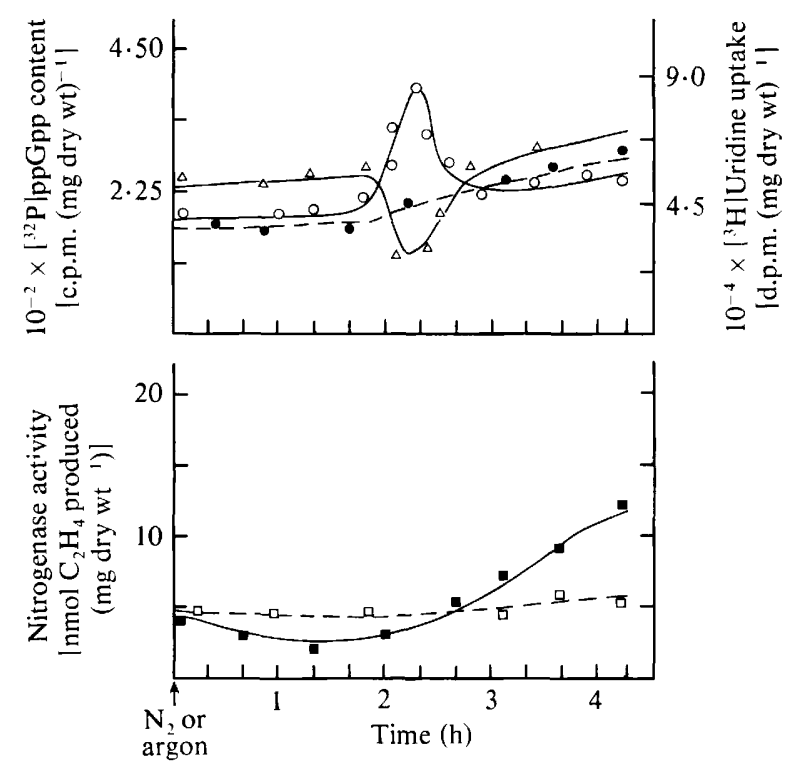

Fig. 6. Changes in $(O, \bigcirc)$ ppGpp concentrations and $(\triangle)$ the rate of $\left[{ }^{3} \mathrm{H}\right]$ uridine uptake before nitrogenase derepression. Cells grown with $12 \mathrm{~mm}-\mathrm{NH}_{+} \mathrm{Cl}$ were harvested, and washed and suspended in ammonia-free growth medium sparged with $\mathrm{N}_{2}(-)$ or argon $(---)$. As soon as the cell sample was resuspended under $\mathrm{N}_{2}$ or argon, a zero time reading was taken. The residual amounts of ammonia prevented nitrogenase expression for approximately $2 \mathrm{~h} . \square, \boldsymbol{\square}$, Nitrogenase activity. Values from four experiments did not vary by more than $\pm 20 \%$.

after $\mathrm{N}$-starvation. After a further $45 \mathrm{~min}$ an increase in $\mathrm{ppGpp}$ was followed by an enhancement of nitrogenase activity (Fig. 6). In cultures where argon substituted for $\mathrm{N}_{2}$ the cells did not accumulate radioactive ppGpp.

\section{DISCUSSION}

During adaptation for growth under denitrifying conditions, cells of $R$. sphaeroides $\mathrm{f}$. sp. denitrificans undergo pronounced physiological changes. The presence of nitrate (effectively nitrite) in photosynthetically grown bacterial cultures results in a drastic reduction of carotenoid and bacteriochlorophyll contents (Michalski \& Nicholas, 1984a), as well as a loss of one of the polypeptides of the light-harvesting complex (Michalski et al., 1985).

Denitrifying cells also have high activities of nitrate and nitrite reductases. Both reductases are constitutive enzymes and it is likely that copies of mR NA for synthesis of these enzymes are 'long-lived' in the cells (Michalski \& Nicholas, 1984a). As shown in this paper (Figs 2-5), the synthesis of nitrate and nitrite reductases was enhanced during growth by their substrates nitrate and nitrite. Both enzymes were active in vitro (with $\mathrm{BVH}$ as an electron donor), and they catalysed the reduction of their substrates at the expense of endogenous electron donors in the light. Thus, in contrast with certain strains and mutants of $R$. capsulata in which dissimilatory reduction of nitrate was inhibited by illumination (McEwan et al., 1982, 1984), the synthesis and activities of denitrifying enzymes in $R$. sphaeroides $\mathrm{f}$. sp. denitrificans were not affected by light during growth. Moreover, it has been shown that denitrifying growth of $R$. sphaeroides $\mathrm{f}$. sp. denitrificans in the dark was much slower than in the light, but in both growth regimes nitrate was denitrified to $\mathrm{N}_{2}$ gas (Satoh et al., 1976; Dunstan et al., 1982). Nitrate reductase is a complex protein which contains cytochrome $c\left(E_{m, 7} 250 \mathrm{mV}\right)$ and accepts electrons from NADH/FMN via a $b$ type cytochrome $\left(E_{m .7} 175 \mathrm{mV}\right)$ (Satoh, 1981; Yokota et al., 1984). Nitrite reductase is a copper protein (Michalski \& Nicholas, 1985) that accepts electrons from reduced cytochrome $c_{2}$ (Sawada et al., 1978). This soluble cytochrome is reduced by the cytochrome $b / c_{1}$ complex and 
also acts as an electron donor to bacteriochlorophyll in a reaction centre (Bartsch, 1978; Shill \& Wood, 1984). Urata \& Satoh (1984) have recently reported that the cytochrome $b / c_{1}$ complex involved in photosynthetic electron transfer also donates electrons to the dissimilatory nitrite reductase via cytochrome $c_{2}\left(E_{m .8} 309 \mathrm{mV}\right)$. Thus, it is possible that the fluxes through these two energy-transducing systems, namely photosynthesis and denitrification, are limited by the availability of reducing equivalents from components of a shared electron transfer chain.

In $R$. sphaeroides $\mathrm{f}$. $\mathrm{sp}$. denitrificans, changes in $\mathrm{ppGpp}$ were recorded in response to the nutritional/energy state of the cells; these were similar to those reported for heterotrophic bacteria (Cashel, 1975; Campbell \& Lenking, 1983; Zumft \& Neumann, 1983). The addition of nitrate or nitrite to washed cells of $R$. sphaeroides $\mathrm{f}$. sp. denitrificans grown either in light or in the dark, resulted in repetitive appearance of 'stringent' signals, e.g. a rapid transient accumulation of ppGpp and a decrease in the rate of $\left[{ }^{3} \mathrm{H}\right]$ uridine uptake (Figs $2-5$ ). Similarly, there was a transient increase of ppGpp before the overproduction of nitrogenase under conditions of $\mathrm{N}$ starvation (Fig. 6, cf. Zumft \& Neumann, 1983).

$R$. sphaeroides f. sp. denitrificans is a dissimilatory denitrifier (Satoh et al., 1976) and neither nitrate nor nitrite can serve as a sole nitrogen source for its growth. Thus, the addition of these two substrates does not change the nutritional status of the cells. The enhancement of the production and activities of nitrate and nitrite reductases by their substrates could, however, result in an imbalance in the distribution of reducing equivalents between the photosynthetic and denitrification linked electron transfer systems. This stress on the electron transfer system could be reflected by the appearance of 'stringent' signals associated with the regulatory system of the cells.

When ascorbate was included in the growth medium, $R$. sphaeroides $\mathrm{f}$. sp. denitrificans did not accumulate ppGpp in response to the addition of either nitrate or nitrite. Under these conditions, however, denitrifying enzymes were still synthesized and were more active than in cells where ascorbate was omitted. Thus, it is possible that ascorbate, a reductant with rather low potential (about $+50 \mathrm{mV}$ ) could donate electrons to the high potential components of the electron transfer chain linked to denitrification [cytochrome $b\left(E_{m} 175 \mathrm{mV}\right)$, cytochrome $c\left(E_{m}\right.$ $250 \mathrm{mV}$ ) or cytochrome $c_{2}\left(E_{m} 309 \mathrm{mV}\right)$; Urata \& Satoh, 1984; Yokota et al., 1984] thus restoring an imbalanced distribution of electrons in denitrifying cells in the light. Hence, our results support the involvement of ppGpp in regulating the metabolism of cells of $R$. sphaeroides $\mathrm{f}$. $\mathrm{sp}$. denitrificans undergoing so-called energy down-shift resulting from the addition of nitrate and/or nitrite to cultures. This effect is similar to that reported to be associated with changes in incident light intensity in R. sphaeroides (Eccleston \& Gray, 1973).

W.P.M. acknowledges with thanks the award of a research associateship by the Australian Research Grants Scheme (ARGS) under a grant to D.J.D.N. We thank David Mathew for skilled technical assistance.

\section{REFERENCES}

Bartsch, R. G. (1978). Cytochromes. In The Photosynthetic Bacteria, pp. 249-279. Edited by R. K. Clayton \& W. R. Sistrøm. New York \& London: Plenum Press.

BRADFORD, M. M. (1976). A rapid and sensitive method for the quantitation of microgram quantities of protein utilizing the principle of protein-dye binding. Analytical Biochemistry 72, 248-254.

Campbell, T. B. \& Leuking, D. R. (1983). Lightmediated regulation of phospholipid synthesis in Rhodopseudomonas sphaeroides. Journal of Bacterio$\log y$ 155, 806-816.

CASHEL, M. (1975). Regulation of bacterial ppGpp and pppGpp. Annual Review of Microbiology 29, 301-318.

Cashel, M., Lazzarini, R. A. \& Kalbacher, B. (1969). An improved method for thin-layer chromatography of nucleotide mixtures containing ${ }^{32} \mathrm{P}$ - labelled orthophosphate. Journal of Chromatography 40, 103-109.

Dunstan, R. H., Kelley, B. C. \& Nicholas, D. J. D. (1982). Fixation of dinitrogen derived from denitrification of nitrate in a photosynthetic bacterium, Rhodopseudomonas sphaeroides f. $\mathrm{sp}$. denitrificans. Journal of Bacteriology 150, 100-104.

ECCleston, E. D. JR \& GRAY, E. D. (1973). Variations in ppGpp levels in Rhodopseudomonas sphaeroides during adaptation to decreased light intensity. Biochemical and Biophysical Research Communications 54, 1370-1376.

Gallant, J. A. (1979). Stringent control in E. coli. Annual Review of Genetics 13, 393-415.

Gallant, J., Shell, L. \& BitTNer, R. (1976). A novel nucleotide implicated in the response of $E$. coli to energy source down-shift. Cell 7, 75-84. 
Hillmer, P. \& Gest, H. (1977). $H_{2}$ metabolism in the photosynthetic bacterium Rhodopseudomonas capsulata: production and utilization of $\mathrm{H}_{2}$ by resting cells. Journal of Bacteriology 129, 724-731.

Kelley, B. C.. Dunstan, R. H. \& Nicholas, D. J. D. (1982). Respiratory dependent nitrogenase activity in the dark in denitrifying phototrophic bacterium Rhodopseudomonas sphaeroides $\mathrm{f}$. $\mathrm{sp}$. denitrificans. FEMS Microbiology Letters 13, 253-258.

LoEwen, P. C. (1976). Novel nucleotides from E. coli isolated and partially characterized. Biochemical and Biophysical Research Communications 70, 1210-1218.

McEwan, A. G., George, Ch. L., Ferguson, S. J. \& JACKSON, J. B. (1982). A nitrate reductase activity in Rhodopseudomonas capsulata linked to electron transfer and generation of a membrane potential. FEBS Letters 150, 277-280.

MCEWAN, A. G., JaCkson, J. B. \& Ferguson, S. J. (1984). Rationalization of properties of nitrate reductases in Rhodopseudomonas capsulata. Archives of Microbiology 137, 344-349.

Michalski, W. P. \& Nicholas, D. J. D. (1984a). The adaptation of Rhodopseudomonas sphaeroides $\mathrm{f}$. sp. denitrificans for growth under denitrifying conditions. Journal of General Microbiology 130, 155-165.

Michalski, W. P. \& Nicholas, D. J. D. $(1984 b)$. Regulation of $\mathrm{N}_{2}$ fixation and ammonia assimilation in Rhodopseudomonas sphaeroides $\mathrm{f}$. $\mathrm{sp}$. denitrificans. Role of glutamine. Journal of General Microbiology 130, 1069-1077.

Michalski, W. P. \& Nicholas, D. J. D. (1985). Molecular characterization of a copper-containing nitrite reductase from Rhodopseudomonas sphaeroides f. sp. denitrificans. Biochimica et biophysica acta 828, 130-137.

Michalski, W. P., Nicholas, D. J. D. \& Whatley, F. R. (1985). Effects of nitrate, nitrite and diphenylamine on the photosynthetic apparatus of Rhodopseudomonas sphaeroides f. sp. denitrificans. Journal of General Microbiology 131, 1951-1961.

Nicholas, D. J. D. \& Nason, A. (1954). Molybdenum as an electron carrier in nitrate reductase action. Archites of Biochemistry and Biophysics 51, 310-312.

Nierlich, D. P. (1978). Regulation of bacterial growth, RNA and protein synthesis. Annual Review. of Microbiology 32, 393-432.

RANDERATH, E. \& RANDERATH, K. (1964). Resolution of complex nucleotide mixtures by two dimensional anion-exchange thin-layer chromatography. Journal of Chromatography 16, 126-129.

SATOH, T. (1981). Soluble dissimilatory nitrate reductase containing cytochrome $c$ from a photodenitrifier Rhodopseudomonas sphaeroides forma $\mathrm{sp}$. denitrificans. Plant and Cell Physiology 22, 443-452.

Satoh, T., Hoshino, Y. \& Kitamura, M. (1976). Rhodopseudomonas sphaeroides forma sp. denitrificans, a denitrifying strain as a sub-species of Rhodopseudomonas sphaeroides. Archices of Microbiology 108, 265-269.

Sawada, E., Satoh, T. \& Kitamura, H. (1978). Purification and properties of a dissimilatory nitrite reductase of a denitrifying phototrophic bacterium. Plant and Cell Physiology 19, 1339-1351.

Shill, D. A. \& Wood, P. M. (1984). A role of cytochrome $c_{2}$ in Rhodopseudomonas viridis. Biochimica et biophysica acta 743, 136-148.

URATA, K. \& SATOH, T. (1984). Evidence for cytochrome $b / c_{1}$ complex involvement in nitrite reduction in a photodenitrifier, Rhodopseudomonas sphaeroides forma sp. denitrificans. FEBS Letters 172, 205208.

Yokota, S., Urata, K. \& Satoh, T. (1984). Redox properties of membrane-bound $b$-type cytochromes and a soluble $c$-type cytochrome of nitrate reductase in a photodenitrifier, Rhodopseudomonas sphaeroides forma sp. denitrificans. Journal of Biochemistry 95 , $1535-1541$.

Zumft, W. G. \& Neumann, S. (1983). Changes in guanosine tetraphosphate (ppGpp) level during nitrogenase expression in the phototrophic bacterium Rhodopseudomonas palustris. FEBS Letters 154, $121-126$. 